Check for updates

Cite this: RSC Adv., 2019, 9, 39735

Received 16th October 2019

Accepted 19th November 2019

DOI: 10.1039/c9ra08478a

rsc.li/rsc-advances

\section{Sulfamic acid promoted one-pot multicomponent reaction: a facile synthesis of 4-oxo- tetrahydroindoles under ball milling conditions $\dagger$}

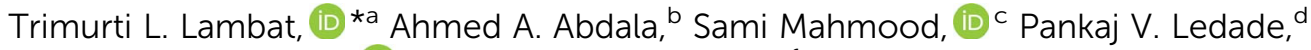 \\ Ratiram G. Chaudhary (D) and Subhash Banerjee ${ }^{\star f}$
}

We report an efficient and facile one-pot synthesis of 4-oxo-tetrahydroindoles using sulfamic acid under ball milling conditions. The present protocol for preparation of biologically important 4-oxotetrahydroindoles offers several advantages such as mild reaction conditions, improved selectivity and higher isolated yields. Moreover, solvent-free reaction conditions and the use of ball milling make the present protocol environmentally friendly in nature.

\section{Introduction}

Ball milling is a mechanochemical procedure that is mainly used to grind minerals and prepare and modify inorganic compounds. ${ }^{1 a}$ Nowadays, its application in synthetic organic chemistry has become an emerging field of research. Examples of the recent applications of ball milling in organic synthesis ${ }^{1 b}$ include $\mathrm{C}-\mathrm{C}$ bond forming reactions, metal-catalyzed $\mathrm{C}-\mathrm{N}, \mathrm{C}-\mathrm{C}$ and $\mathrm{C}-\mathrm{F}$ bond development, ${ }^{1, \boldsymbol{d}}$ organo-catalyzed $\mathrm{C}-\mathrm{C}$ bond formation, ${ }^{1 e}$ cycloaddition reactions, ${ }^{1 f}$ synthesis of heterocycles, ${ }^{1 g}$ protecting group chemistry, ${ }^{1 h}$ redox processes,${ }^{1 i}$ reactions with fullerenes and bromination reactions.${ }^{1 j}$ Compared to conventional solution phase reactions, ball milling conditions commonly yield increased selectivity and reactivity, and thus there should be further exploration of applications of ball milling in organic synthesis. ${ }^{1 k}$

On the other hand, multicomponent reactions (MCRs) ${ }^{2 a}$ provide attractive synthetic approach in the fields of organic and medicinal chemistry ${ }^{2 b}$ due to their higher atom economy, structural variability, selective bond formation ability and

\footnotetext{
${ }^{a}$ Department of Chemistry, Manoharbhai Patel College of Arts, Commerce \& Science, Deori, Dist-Gondia 441901, Maharashtra, India. E-mail: lambatges@gmail.com; Tel: $+917972047470$

${ }^{b}$ Chemical Engineering Program, Texas A \& M University at Qatar, POB 23784, Doha, Qatar

'Department of Physics, The University of Jordan, Amman 11942, Jordan

${ }^{d}$ Department of Chemistry, Yashwantrao Chawhan Arts, Commerce \& Science College, Lakhandur, Bhandara 441803, Maharashtra, India

${ }^{e}$ Post Graduate Department of Chemistry, S. K. Porwal College of Arts, Commerce \& Science, Kamptee-441001, India

${ }^{f}$ Department of Chemistry, Guru Ghasidas Vishwavidyalaya, Bilaspur, 495009, Chhattisgarh, India. E-mail: ocsb2006@gmail.com; Fax: +917752260148; Tel: +917587401979

$\dagger$ Electronic supplementary information (ESI) available. See DOI: $10.1039 / \mathrm{c} 9 \mathrm{ra} 08478 \mathrm{a}$
}

simplicity to perform relative to the conventional multistep reactions. ${ }^{2 c}$ Further, the MCR is performed in a single step which does not require isolation of the intermediates, leading to a favourable reduction of the reaction time and energy. Additionally, solvent-free reaction is a promising approach in organic synthesis it does not produce unwanted solvent waste. ${ }^{2 d}$ Conventionally, solvent-free reactions have been performed via a mortar and pestle, but recently high-energy ball milling (HEBM) was realized as a more attractive alternative. Although ball milling is a technique that works according to the same principles as traditional mortar and pestle, its mechanical energy is usually high enough to facilitate a chemical reaction. ${ }^{2 e}$ Many reports have demonstrated the effectiveness of HEBM for organic transformations and development of environmentally benign synthetic processes. ${ }^{2 f}$ Due to the aforementioned advantages, MCRs found numerous applications ${ }^{2 g}$ in the synthesis of drugs and new biologically important active organic scaffolds. ${ }^{2 h}$

Heterocyclic motifs are critical in drug discovery because of their vast array of applications in the agrochemicals, pharmaceuticals and veterinary fields. ${ }^{3 a}$ Among others, tetrahydroindole $^{3 b}$ and indole related moieties ${ }^{3 c}$ impart distinct and interesting structural features with various biological characteristics such as progesterone receptor agonist, ${ }^{3 d}$ inhibitor at vanilloid receptor-1, MDM2-p53 interaction inhibitor, ${ }^{3 e}$ antimalarial, antituberculotic, ${ }^{3 f} \mathrm{CR} \mathrm{TH}_{2}$ receptor antagonist and Satavaptan. Representative bioactive molecular structures are provided in (Fig. 1).

Because of these important applications of heterocyclic compounds, different synthetic methods were developed for their production..$^{4 a-d}$ However, most the methods are metal catalysed $^{4 e}$ and have several limitations such as harsh reaction conditions, employment of toxic and expensive metals as catalysts, longer reaction time, non-reusability of catalysts etc. ${ }^{4 f, g}$ The dimedone reacts with $\alpha$-chloroacetaldehyde in sodium 

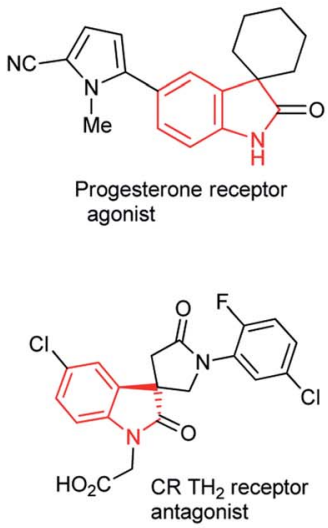
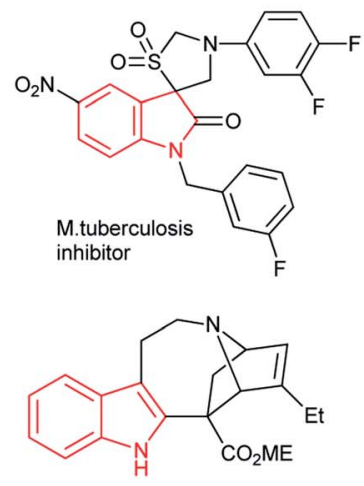

Catharanthine<smiles>CCC1CC(=O)CC(c2cccc(Cl)c2)C12C(=O)Nc1cc(Cl)ccc12</smiles>

inhibitor<smiles>COc1ccc2[nH]c3c(c2c1)CCNC3C(=O)O</smiles>

$\mathrm{MK}^{-2}$ inhibitor

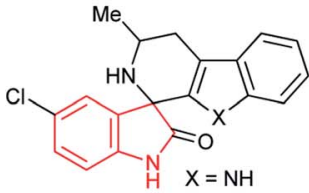

Antimalarial

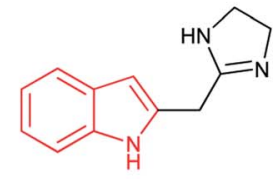

antidepressant agent<smiles>NC(=O)CCc1[nH]c2ccccc2c1Sc1cc(Cl)cc(Cl)c1</smiles>

antiviral against vaccinia<smiles>N[C@@H](Cc1[nH]c2ccc(O)cc2c1CCF)C(=O)O</smiles>

radiotracers for tumor imaging

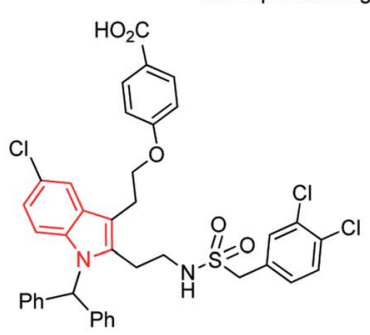

Fig. 1 Biologically important compounds possessing 2-oxoindole and indole scaffolds.

carbonate to produced 4-oxo tetrahydrofuran which reacts with ammonium hydroxide to gives 4-oxo tetrahydroindole in another route depicted in (Scheme 1). ${ }^{4 e_{f} f}$

Therefore, the design of effective and facile approaches for creation of these derivatives is of utmost importance. ${ }^{5 a}$ Moreover, heterogeneous acidic catalysts are more successful than their homogeneous counterparts because of their ease of separation and retrieval for cyclic use making the process more economical. ${ }^{5 b}$ On the other hand, sulfamic acid $\left(\mathrm{H}_{2} \mathrm{NSO}_{3} \mathrm{H}\right.$, sulfamic acid $)^{5 c}$ has been recently proven as very effective in promoting acid-catalyzed reactions due to its low cost, higher stability, resistance to corrosion, non-hygroscopic, and nonvolatile nature. ${ }^{5 d, e}$ In addition, miscibility of sulfamic acid with water makes it easily recyclable. Sulfamic acid is used as promoter for protection of aliphatic substrate, Beckmann rearrangement, ${ }^{5 f}$ Hantzsch reaction, ${ }^{5 g}$ Biginelli reaction, ${ }^{5 h}$ Pechmann condensation, ${ }^{5 i}$ Michael addition ${ }^{5 j}$ and Mannich reactions. ${ }^{5 k}$
In contribution to development of environmentally benign protocols for bioactive heterocyclic compounds synthesis, we report a facile, low-cost and green approach to synthesize 4-oxotetrahydroindoles using sulfamic acid under ball milling condition following (Scheme 2).

\section{Result \& discussion}

To begin the study, the reaction of dimedone (1), phenacyl bromide (2), and aniline (3) was chosen as a model substrate in the ball mill. In our first attempt the reaction was conducted in the absence of catalyst by milling for $60 \mathrm{~min}$ at a milling rotational speed of $600 \mathrm{rpm}$, the product, 6-dimethyl-1,2-diphenyl1,5,6,7-tetrahydro- $4 \mathrm{H}$-indol-4-one (4a) was isolated with $10 \%$ yield (entry 1, Table 1). Then different types of catalysts like $\mathrm{SiO}_{2}, \mathrm{PMA}_{-} \mathrm{SiO}_{2}$, Amberlite, Montmorillonite K10, Indion resin, and Wang sulfonic acid were incorporated and milled for $60 \mathrm{~min}$ at $600 \mathrm{rpm}$. The isolated product revealed a yield
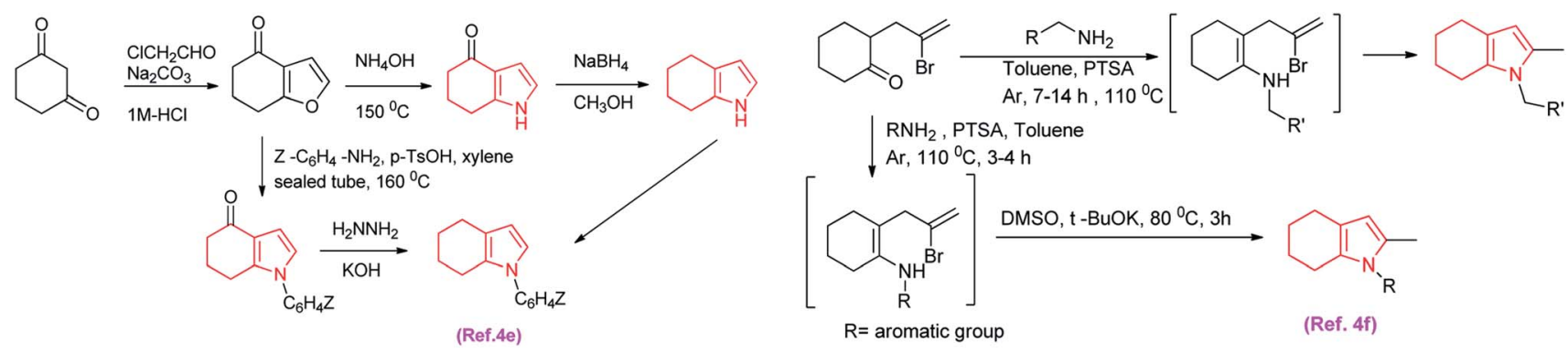

Scheme 1 Conventional approach for the synthesis of tetrahydroindole derivatives. 

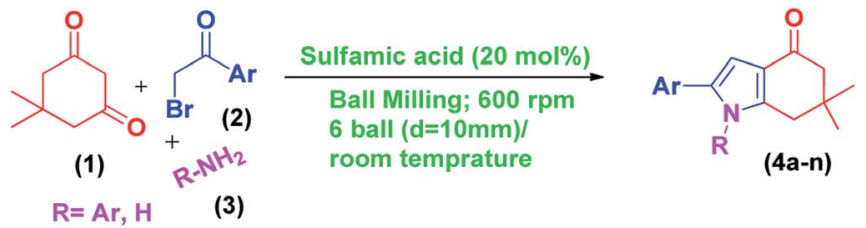

Scheme 2 General reaction scheme of sulfamic acid catalyzed for synthesis of 4-oxo-tetrahydroindoles scaffolds under ball milling conditions.

increase up to $24-62 \%$ (entry $2-7$, Table 1 ). However, the product yield using sulfamic acid was significantly higher (entry 8 , Table 1). A mixture of model substrate and sulfamic acid (15 mol\%) milled for $60 \mathrm{~min}$ at rotation speed of $600 \mathrm{rpm}$ yielded $92 \%$ (4a) without column chromatography.

In order to study the effect of ball milling conditions and amount of sulfamic acid on the yield, sulfamic acid loading was varied between 5 to $25 \mathrm{~mol} \%$ and the ball milling speed was varied between 400-600 rpm and the reaction time was either 60 or 90 minutes. Therefore, following the experimental procedure (ESI $\dagger$ for detail experimental procedure) and the aforementioned conditions, the yield of (4a) using sulfamic acid varied between $88-98 \%$ with the optimum conditions at loading of $20 \mathrm{~mol} \%$ (Fig. 2).

With the optimal conditions, we investigated possible scopes of reactants as revealed in (Table 2). All of these 4-oxotetrahydroindoles are identified motifs and were simply recognized by assessment of their spectroscopic information with those previously reported ${ }^{4 g}$ (ESI for spectroscopic data; $\mathrm{S} 2 \dagger$ ). The phenacyl bromide consists of both electron withdrawing (e.g. - $\mathrm{CN}$ group) and electron donating (e.g. $-\mathrm{Cl},-\mathrm{OCH}_{3}$ etc.) groups participated proficiently in the reaction not together with a few electronic effects. The aromatic amine having presence of electron donating groups (e.g. - Me, -naphthyl, $-\mathrm{F},-\mathrm{Cl}$,

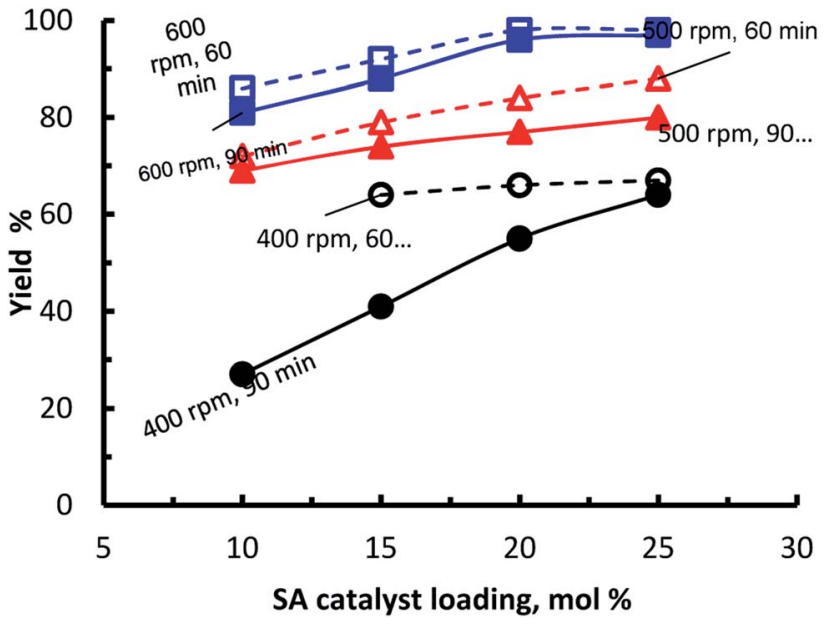

Fig. 2 Effect of sulfamic acid loading and reaction conditions on the yield of $(4 a)$.

- $\mathrm{Br}$, -cyclopropyl, - $n$-butyl etc.) increase the reaction rate as well as the product yields. The findings were depicted in (Table 2). The synthesized 4-oxo-tetrahydroindoles were purified by recrystallization from hot ethanol and thus, column chromatography is not required in the present protocol. Their structure was confirmed by measuring the melting points $\left(\mathrm{MP}{ }^{\circ} \mathrm{C}\right)$ followed by spectroscopic characterization using nuclear magnetic resonance $\left({ }^{1} \mathrm{H} \mathrm{NMR},{ }^{13} \mathrm{C} \mathrm{NMR}\right.$ and mass spectra); spectra were provided in (ESI for copies of spectra; $\mathrm{S} 3 \dagger$ ).

The plausible mechanistic pathway for this three-component one-pot reaction is revealed in (Scheme 3). In the first step, dimedone (1) containing active methylene group undergoes alkylation with the phenacyl bromide (2) to produced tricarbonyl compound (A). In the existence of the sulfamic acid, primary amine (3) can react with one of the keto groups of

Table 1 Optimization of reaction conditions for the synthesis of (4a) using ball milling

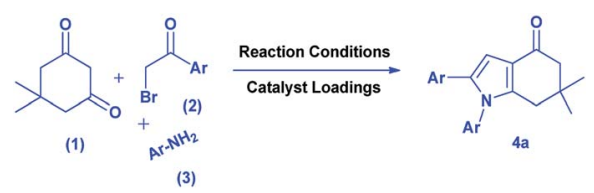

\begin{tabular}{|c|c|c|c|c|c|}
\hline Entry & Catalysts or additive & Catalyst (mol\%) & Rotation (rpm) & Time (min) & Yield $^{a}(\%)$ \\
\hline 1 & No catalyst & - & 600 & 60 & 10 \\
\hline 2 & $\mathrm{SiO}_{2}$ & 20 & 600 & 60 & 33 \\
\hline 4 & Amberlite & 20 & 600 & 60 & 41 \\
\hline 5 & MMT K-10 clay & 20 & 600 & 60 & 40 \\
\hline 6 & Indion resin & 20 & 600 & 60 & 24 \\
\hline
\end{tabular}

${ }^{a}$ Isolated yield; model reaction (4a): dimedone (140.18 mg, $1.0 \mathrm{mmol}$ ), phenacyl bromide (199.04 mg, $\left.1.0 \mathrm{mmol}\right)$, and aniline (93.13 mg, $\left.1.0 \mathrm{mmol}\right)$ under ball milling. ${ }^{b}$ Present work. 
Table 2 Sulfamic acid catalyzed synthesis of 4-oxo-tetrahydroindoles derivatives

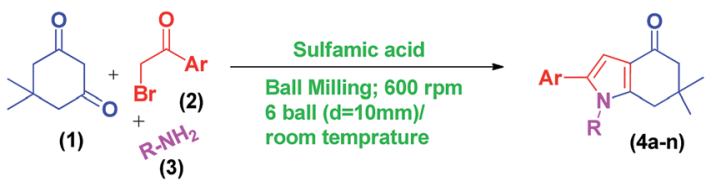

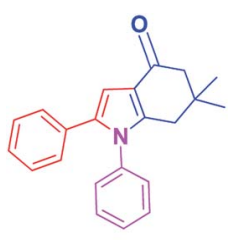

4a, Yield $98 \%$

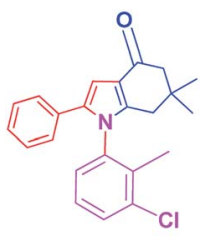

4e, Yield $89 \%$

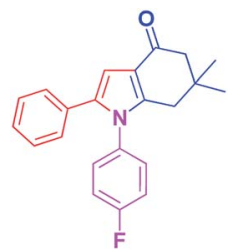

4i, Yield $84 \%$

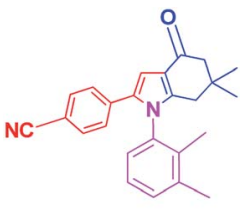

$4 \mathrm{~m}$, Yield $86 \%$

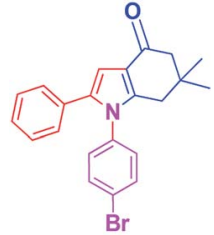

$4 b$, Yield $93 \%$

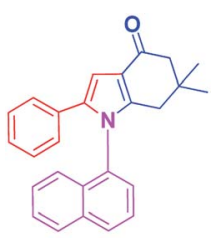

4f, Yield $88 \%$

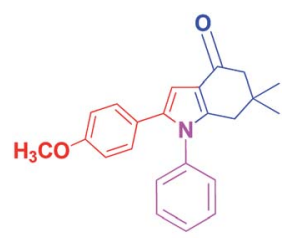

4j, Yield 93\%

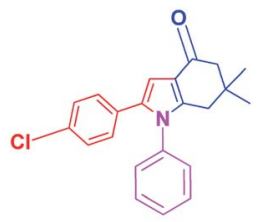

4n, Yield $90 \%$

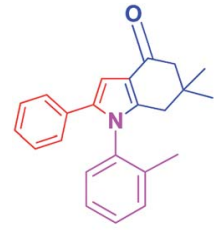

4c, Yield $95 \%$

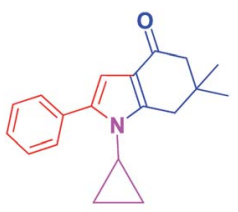

4g, Yield 92\%

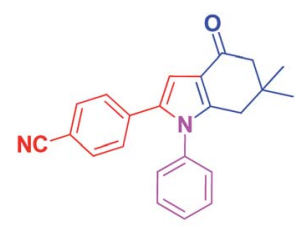

$4 k$, Yield $88 \%$

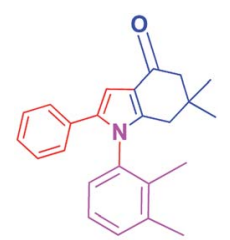

4d, Yield $91 \%$

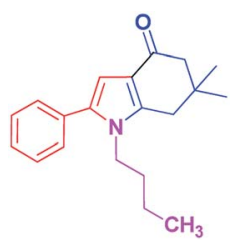

4h, Yield 91\%

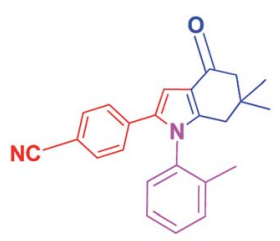

4I, Yield 91\% dimedone to produced an intermediate (B) followed by loss of water molecule giving $N$-alkylenamine (C). The amino group of $\mathrm{N}$-alkylenamine (C) can attack on the carbonyl group of phenacyl bromide specifically to generate an intermediate (D). In the presence of sulfamic acid undergo cyclization to produced (E) and followed by loss of water molecule furnishes the product (4a).

In order to assess the effect of various Brønsted acids, we carried out the reaction between dimedone $(140.18 \mathrm{mg}, 1.0$ mmol), phenacyl bromide (199.04 mg, $1.0 \mathrm{mmol}$ ), and aniline ( $93.13 \mathrm{mg}, 1.0 \mathrm{mmol}$ ) at refluxing conditions in $\mathrm{EtOH}$, catalyzed by using $20 \mathrm{~mol} \%$ of various additives (Table 3). The reaction afforded the product (4a) although the yield was low as compared with ball milling condition (compare with entry 8 in Table 1).

To signify the advantage of the current methodology, a comparative study of current and earlier known methods is provided in (Table 4) which clarifies the effectiveness of the sulfamic acid promoter compared with the known Wang resin supported sulfonic acid ${ }^{4 g}$ in terms of reaction time, product yield and catalyst recyclability.

Next, we have investigated the reusability of sulfamic acid for the synthesis of (4a) as a model reaction in $2 \mathrm{mmol}$ scale. After reaction, sulfamic acid was retrieved from the reaction mixture by simple filtration, consequently washed with aqueous ethanol, dried and reused for the next cycle. We confirmed that sulfamic acid can be effectively recycled for five cycles without appreciable loss of catalytic activity. However, a little $(\sim 12 \%)$ loss in the yield of the product was observed. The results were presented in (Fig. 3). The decrease of the yield could be due to loss of sulfamic acid $(\sim 8.5 \%)$ during reaction and recycling.

\section{Experimental}

\section{General}

The chemicals were procured from S. D. Fine, India and Merck Ltd. without additional purification. The sulfamic acid was purchased from Merck Ltd. (catalogue no. 242780). The 


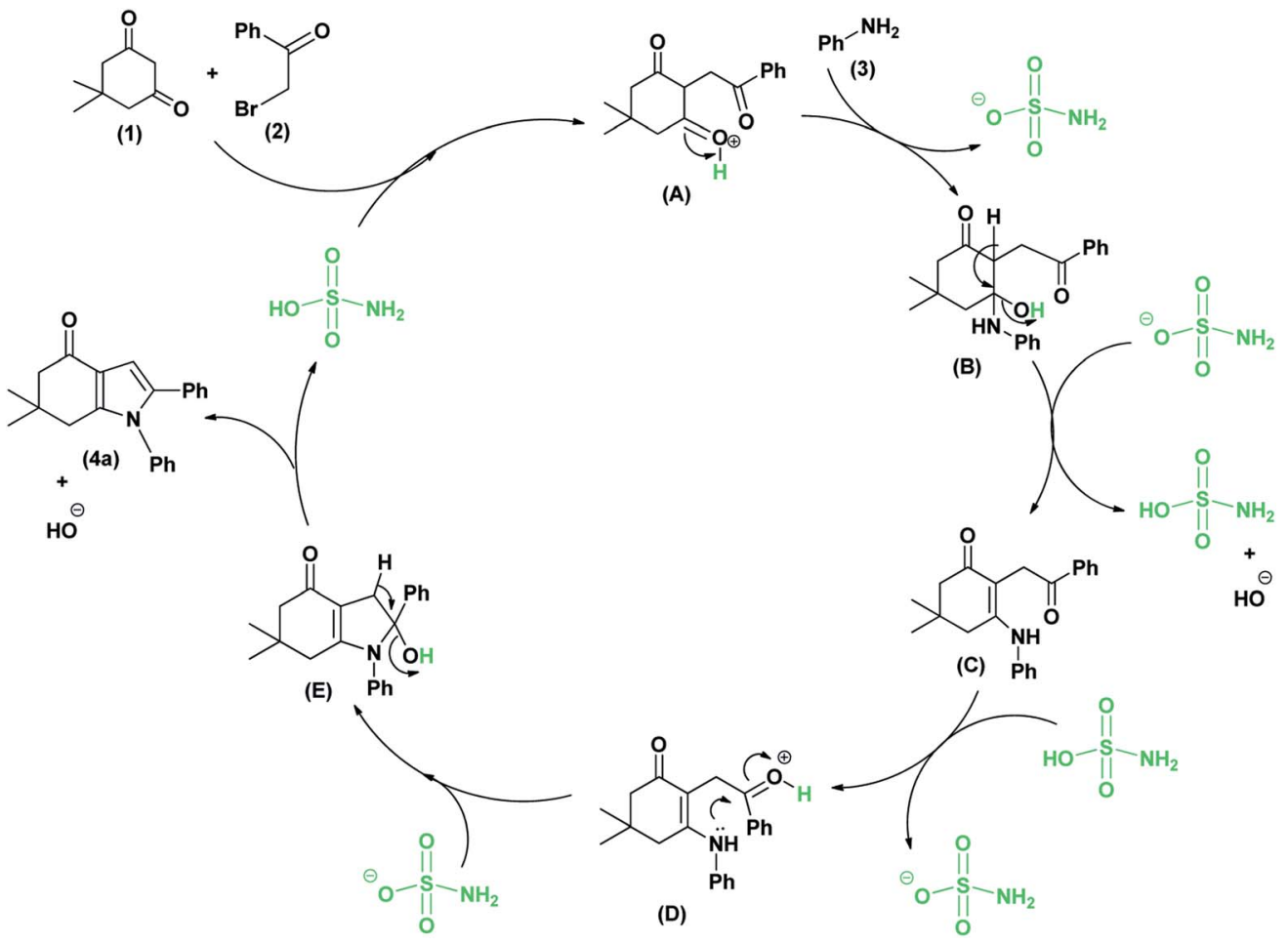

Scheme 3 Plausible mechanism for the synthesis of 4-oxo-tetrahydroindole (4a) using sulfamic acid.

reactions were monitored by thin-layer chromatography (TLC) on silica gel plates (60 F254), visualizing with ultraviolet light or iodine spray. Flash chromatography was performed on silica gel (100-200 mesh) using distilled hexane, ethyl acetate, and dichloromethane. A Retsch 01.462.0220 Agate Grinding Jar (250 mL capacity) was used for the Planetary Ball Mill 100. All the products were identified compounds and their physical information, FT-IR, mass spectra and ${ }^{1} \mathrm{H}$ NMR was basically the same as those of the genuine samples. Melting points were determined using melting point B-540 apparatus and are uncorrected. HRMS was determined using waters LCT premier XETOF ARE-047 apparatus.

General procedure for synthesis of 4-oxo-tetrahydroindoles derivatives using ball milling technique: representative experimental procedure for the synthesis of 6,6-dimethyl-1,2diphenyl-1,5,6,7-tetrahydro-4H-indol-4-one (4a)

The mixture of dimedone (140.18 mg; $1 \mathrm{mmol}$ ), phenacyl bromide (199.04 mg; $1 \mathrm{mmol})$, and aniline (93.13 mg; $1 \mathrm{mmol})$ and catalytic amount of sulfamic acid $(19.50 \mathrm{mg} ; 20 \mathrm{~mol} \%)$ was

Table 3 Comparison of Brønsted acids catalyzed conventional methods for synthesis of (4a)

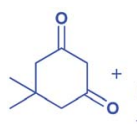

(1)

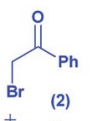

$\underset{\text { Conventional Method }}{\stackrel{\text { Reflux/EtOH }}{\longrightarrow}}$

(3)

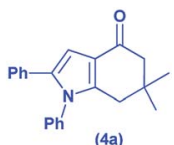

(4a)

\begin{tabular}{|c|c|c|c|c|c|}
\hline Entry & Additives & $(\mathrm{mol} \%)$ & Reaction conditions & Time (min) & Yield $^{a}(\%)$ \\
\hline 1 & TFA & 20 & Reflux/EtOH & 180 & 69 \\
\hline 2 & $\mathrm{C}_{6} \mathrm{H}_{5} \mathrm{CO}_{2} \mathrm{H}$ & 20 & Reflux/EtOH & 240 & 61 \\
\hline 3 & $\mathrm{C}_{6} \mathrm{H}_{5} \mathrm{SO}_{3} \mathrm{H}$ & 20 & Reflux/EtOH & 180 & 78 \\
\hline 4 & $p-\mathrm{CH}_{3} \mathrm{C}_{6} \mathrm{H}_{4} \mathrm{SO}_{3} \mathrm{H}$ & 20 & Reflux/EtOH & 180 & 71 \\
\hline 5 & $\mathrm{AcOH}$ & 20 & Reflux/EtOH & 480 & 45 \\
\hline 6 & Sulfamic $\operatorname{acid}^{b}$ & 20 & Reflux/EtOH & 360 & 84 \\
\hline
\end{tabular}

${ }^{a}$ Isolated yield; model reaction (4a): dimedone (140.18 mg, $1.0 \mathrm{mmol}$ ), phenacyl bromide (199.04 mg, $\left.1.0 \mathrm{mmol}\right)$, and aniline (93.13 mg, $1.0 \mathrm{mmol}$ ) under conventional reflux. ${ }^{b}$ Present work. 
Table 4 Comparative study of the present and reported methods for synthesis of (4a)

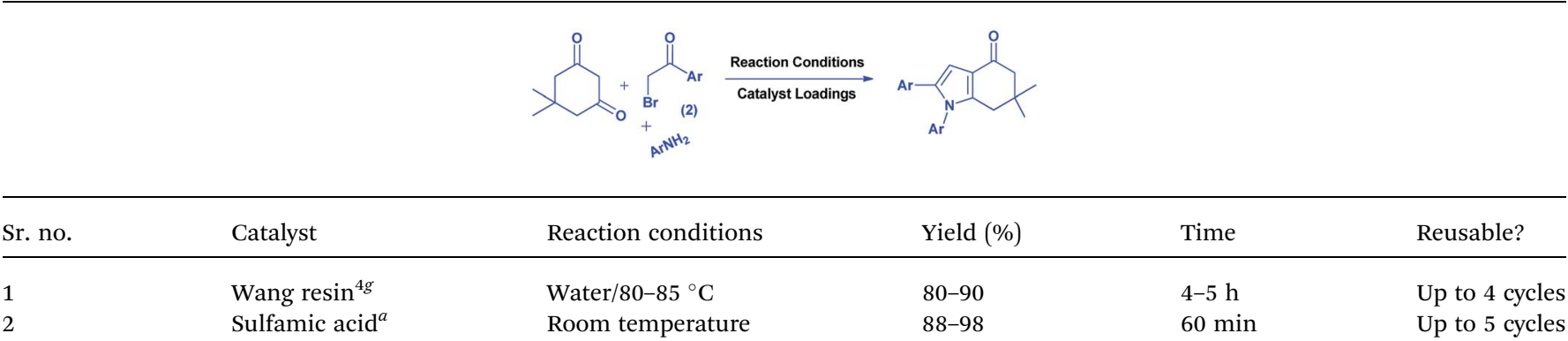

${ }^{a}$ Present work.

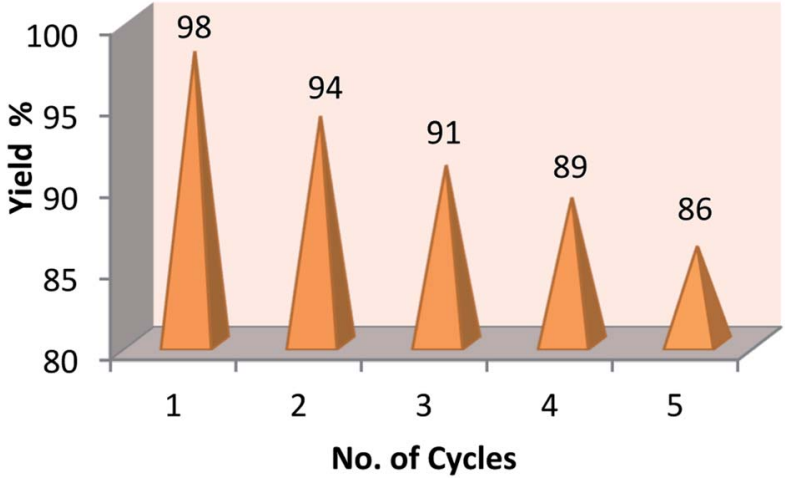

Fig. 3 Recyclability of sulfamic acid for the synthesis (4a) as a model reaction.

taken in one pot under solvent/additives free under ball-milling at $600 \mathrm{rpm}$ with six balls $(d=10 \mathrm{~mm})$ of the equivalent substance using $25 \mathrm{~mL}$ stainless steel beaker for $60 \mathrm{~min}$. The ball-milling was carried out at inverted rotation directions, for time durations of $10 \mathrm{~min}$ separated by intervals of $30 \mathrm{~s}$. The extraction of the reaction residue was accomplished by elution with ethanol $(5 \mathrm{~mL})$, acetone $(2.5 \mathrm{~mL})$ followed by solvent evaporation and recrystallization to provide 6,6-dimethyl-1,2diphenyl-1,5,6,7-tetrahydro- $4 H$-indol-4-one as yellow solid in $98 \%$ yield. This experimental procedure was followed for the synthesis of all products listed in (Table 2).

\section{General procedure for recycling of sulfamic acid}

The reusability of the sulfamic acid was investigated for the synthesis of 6,6-dimethyl-1,2-diphenyl-1,5,6,7-tetrahydro- $4 H_{\text {- }}$ indol-4-one (4a) as a model reaction in $2 \mathrm{mmol}$ scale. Sulfamic acid was separated from the reaction mixture through filtration, washed thoroughly with ethanol $(2 \times 1 \mathrm{~mL})$ followed by acetone $(2 \times 1 \mathrm{~mL})$, dried under oven and reused for the subsequent cycle. We have observed that after five consecutive cycles there was $8.5 \%$ loss of sulfamic acid during reactions and recycling process.

\section{Analytical dada for all synthesized products}

6,6-Dimethyl-1,2-diphenyl-1,5,6,7-tetrahydro-4H-indol-4-one (4a). ${ }^{1} \mathrm{H} \mathrm{NMR}\left(\mathrm{CDCl}_{3}, 400 \mathrm{MHz}\right) \delta: 1.10$ (s, 6H), 2.42 (s, 2H), 2.51 (s, 2H), $6.78(\mathrm{~s}, 1 \mathrm{H}), 7.05-7.07(\mathrm{~m}, 2 \mathrm{H}), 7.12-7.17(\mathrm{~m}, 5 \mathrm{H}), 7.39-$ $7.41(\mathrm{~m}, 3 \mathrm{H}) ;{ }^{13} \mathrm{C} \mathrm{NMR}\left(\mathrm{CDCl}_{3}, 100 \mathrm{MHz}\right) \delta: 28.6$ (2C), 35.5, 37.0, 52.1, 105.6, 120.0, 122.5, 126.8, 127.7 (2C), 128.1 (2C), 128.1 (2C), 128.2, 129.3 (2C), 136.3, 137.7, 144.7, 194.0; HRMS (ESI) [M +1 ] calcd for $\mathrm{C}_{22} \mathrm{H}_{22} \mathrm{NO}$ : 316.1702, found: 316.1691 .

1-(4-Bromophenyl)-6,6-dimethyl-2-phenyl-1,5,6,7-tetrahydro$4 \boldsymbol{H}$-indol-4-one (4b). ${ }^{1} \mathrm{H} \mathrm{NMR}\left(\mathrm{CDCl}_{3}, 400 \mathrm{MHz}\right) \delta: 1.10(\mathrm{~s}, 6 \mathrm{H})$, $2.41(\mathrm{~s}, 2 \mathrm{H}), 2.50(\mathrm{~s}, 2 \mathrm{H}), 6.77(\mathrm{~s}, 1 \mathrm{H}), 7.00-7.03(\mathrm{~m}, 2 \mathrm{H}), 7.04-$ $7.07(\mathrm{~m}, 2 \mathrm{H}), 7.18-7.20(\mathrm{~m}, 3 \mathrm{H}), 7.52(\mathrm{dd}, J 1,2=2.0 \mathrm{~Hz}, J 1,3=$ $6.8 \mathrm{~Hz}, 2 \mathrm{H}) ;{ }^{13} \mathrm{C} \mathrm{NMR}\left(\mathrm{CDCl}_{3}, 100 \mathrm{MHz}\right) \delta: 28.6$ (2C), 35.5, 37.0, 52.0, 105.9, 120.2, 122.1, 127.1, 128.2 (2C), 128.3, 129.2 (2C), 131.5 (2C), 132.5 (2C), 136.2, 136.6, 144.4, 193.8; HRMS (ESI) [M +1 ] calcd for $\mathrm{C}_{22} \mathrm{H}_{21} \mathrm{NOBr}$ : 394.0808, found: 394.0811 .

6,6-Dimethyl-2-phenyl-1-(o-tolyl)-1,5,6,7-tetrahydro-4Hindol-4-one (4c). ${ }^{1} \mathrm{H}$ NMR $\left(\mathrm{CDCl}_{3}, 400 \mathrm{MHz}\right) \delta: 1.05(\mathrm{~d}, J=$ $9.6 \mathrm{~Hz}, 6 \mathrm{H}), 1.86(\mathrm{~s}, 3 \mathrm{H}), 2.15(\mathrm{~d}, J=16 \mathrm{~Hz}, 1 \mathrm{H}), 2.36-2.50(\mathrm{~m}$, $3 \mathrm{H}), 6.83$ (s, 1H), 7.08-7.14 (m, 5H), 7.2-7.36 (m, 4H); ${ }^{13} \mathrm{C}$ NMR $\left(\mathrm{CDCl}_{3}, 100 \mathrm{MHz}\right) \delta: 17.4,27.9,29.2,35.5,36.5,52.1,104.9$, 119.7, 126.9 (2C), 127.4 (2C), 128.1 (2C), 128.6, 129.1, 131.2, 132.0, 136.1 136.4 136.9, 144.8, 193.9; HRMS (ESI) $[\mathrm{M}+1]$ calcd for $\mathrm{C}_{23} \mathrm{H}_{24} \mathrm{NO}: 330.1859$, found: 330.1847 .

1-(2,3-Dimethylphenyl)-6,6-dimethyl-2-phenyl-1,5,6,7-tetrahydro-4H-indol-4-one (4d). ${ }^{1} \mathrm{H}$ NMR $\left(\mathrm{CDCl}_{3}, 400 \mathrm{MHz}\right) \delta: 1.07$ (s, $3 \mathrm{H}), 1.10(\mathrm{~s}, 3 \mathrm{H}), 1.74(\mathrm{~s}, 3 \mathrm{H}), 2.15(\mathrm{~d}, J=16 \mathrm{~Hz}, 1 \mathrm{H}), 2.26(\mathrm{~s}, 3 \mathrm{H})$, 2.40-2.47 (m, 3H), 6.82 (s, 1H), 7.06-7.09 (m, 3H), 7.12-7.14 (m, $3 \mathrm{H}), 7.18-7.19(\mathrm{~m}, 1 \mathrm{H}), 7.22-7.23(\mathrm{~m}, 1 \mathrm{H}) ;{ }^{13} \mathrm{C} \mathrm{NMR}\left(\mathrm{CDCl}_{3}, 100\right.$ MHz) $\delta: 13.9,20.3,27.9,29.1,35.5,36.5,52.1,104.8,119.5$, 126.1, 126.8, 127.4 (2C), 128.1 (2C), 130.1, 130.4, 132.0, 133.4, 136.6, 136.8, 138.6, 145.1, 194.0; HRMS (ESI) [M + 1] calcd for $\mathrm{C}_{24} \mathrm{H}_{26} \mathrm{NO}$ : 344.2014, found: 344.2012 .

1-(3-Chloro-2-methylphenyl)-6,6-dimethyl-2-phenyl-1,5,6,7tetrahydro-4H-indol-4-one (4e). ${ }^{1} \mathrm{H}$ NMR $\left(\mathrm{CDCl}_{3}, 400 \mathrm{MHz}\right) \delta$ : $1.52(\mathrm{~s}, 3 \mathrm{H}), 1.55(\mathrm{~s}, 3 \mathrm{H}), 2.34(\mathrm{~s}, 3 \mathrm{H}), 2.60(\mathrm{~d}, J=16.4 \mathrm{~Hz}, 1 \mathrm{H})$, 2.85-2.87 (m, 2H), 2.90 (d, $J=2.8 \mathrm{~Hz}, 1 \mathrm{H}), 7.26(\mathrm{~s}, 1 \mathrm{H}), 7.49(\mathrm{~d}, J$ $=2.0 \mathrm{~Hz}, 2 \mathrm{H}), 7.50-7.60(\mathrm{~m}, 3 \mathrm{H}), 7.61-7.67(\mathrm{~m}, 1 \mathrm{H}), 7.88-7.93$ $(\mathrm{m}, 2 \mathrm{H}) ;{ }^{13} \mathrm{C} \mathrm{NMR}\left(\mathrm{CDCl}_{3}, 100 \mathrm{MHz}\right) \delta: 15.0,27.9,29.1,35.6$, 36.5, 52.0, 105.2 , 119.9, 127.3 (2C), 128.3 (2C), 129.3 (2C), 130.1, 131.6, 133.6, 135.0, 135.8, 136.7, 138.1, 144.8, 194.0; HRMS (ESI) $[\mathrm{M}+1]$ calcd for $\mathrm{C}_{23} \mathrm{H}_{23} \mathrm{NO}$ : 364.1468, found: 364.1455 .

6,6-Dimethyl-1-(naphthalen-1-yl)-2-phenyl-1,5,6,7-tetrahydro-4H-indol-4-one (4f). ${ }^{1} \mathrm{H}$ NMR $\left(\mathrm{CDCl}_{3}, 400 \mathrm{MHz}\right) \delta: 1.02(\mathrm{~s}$, $6 \mathrm{H}), 2.13(\mathrm{~d}, J=16.4 \mathrm{~Hz}, 1 \mathrm{H}), 2.32-2.42(\mathrm{~m}, 3 \mathrm{H}), 6.91(\mathrm{~s}, 1 \mathrm{H})$, 
7.01-7.36 (m, 5H), 7.46-7.49 (m, 2H), 7.50-7.56 (m, 3H), 7.92$7.95(\mathrm{~m}, 2 \mathrm{H}) ;{ }^{13} \mathrm{C} \mathrm{NMR}\left(\mathrm{CDCl}_{3}, 100 \mathrm{MHz}\right) \delta: 28.0,28.8,35.5,36.3$, 52.1, 105.1, 119.8, 122.5, 125.2, 126.5, 126.8 (2C), 127.5 (2C), 127.7 (2C), 128.3 (2C), 129.3, 130.9, 131.8, 134.0, 134.2, 137.5, 146.1, 194.0; HRMS (ESI) [M +1] calcd for $\mathrm{C}_{26} \mathrm{H}_{24} \mathrm{NO}: 366.1858$, found: 366.1850 .

1-Cyclopropyl-6,6-dimethyl-2-phenyl-1,5,6,7-tetrahydro-4Hindol-4-one (4g). ${ }^{1} \mathrm{H}$ NMR $\left(\mathrm{CDCl}_{3}, 400 \mathrm{MHz}\right) \delta$ : 0.55-0.60 (m, 2H), 0.85-0.95 (m, 2H), $1.17(\mathrm{~s}, 6 \mathrm{H}), 2.37(\mathrm{~s}, 2 \mathrm{H}), 2.80(\mathrm{~s}, 2 \mathrm{H})$, 3.20-3.24 (m, 1H), 6.54 (s, 1H), 7.31-7.33 (m, 1H), 7.36-7.40 (m, $2 \mathrm{H}), 7.45-7.47(\mathrm{~m}, 2 \mathrm{H}) ;{ }^{13} \mathrm{C} \mathrm{NMR}\left(\mathrm{CDCl}_{3}, 100 \mathrm{MHz}\right) \delta: 9.2(2 \mathrm{C})$, 27.0, 28.7 (2C), 35.5, 37.2, 51.9, 104.6, 119.0, 127.0, 128.1 (2C), 128.3 (2C), 132.8, 137.0, 146.0, 193.6; HRMS (ESI) [M + 1] calcd for $\mathrm{C}_{19} \mathrm{H}_{22} \mathrm{NO}: 280.1701$, found: 280.1707 .

1-Butyl-6,6-dimethyl-2-phenyl-1,5,6,7-tetrahydro-4H-indol-4one (4h). ${ }^{1} \mathrm{H}$ NMR $\left(\mathrm{CDCl}_{3}, 400 \mathrm{MHz}\right) \delta: 0.77(\mathrm{t}, J=7.6 \mathrm{~Hz}, 3 \mathrm{H})$, 1.10-1.19 (m, 2H), 1.25 (s, 6H), 1.46-1.52 (m, 2H), $2.36(\mathrm{~s}, 2 \mathrm{H})$, $2.67(\mathrm{~s}, 2 \mathrm{H}), 3.83(\mathrm{t}, J=7.6 \mathrm{~Hz}, 2 \mathrm{H}), 6.53(\mathrm{~s}, 1 \mathrm{H}), 7.34-7.42(\mathrm{~m}$, $3 \mathrm{H}), 7.42-7.49(\mathrm{~m}, 1 \mathrm{H}), 7.58-7.62(\mathrm{~m}, 1 \mathrm{H}) ;{ }^{13} \mathrm{C} \mathrm{NMR}\left(\mathrm{CDCl}_{3}, 100\right.$

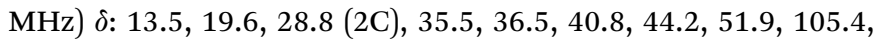
119.2, 127.7, 128.4 (2C), 129.2 (2C), 130.1, 133.6, 143.3, 193.7; HRMS (ESI) $[\mathrm{M}+1]$ calcd for $\mathrm{C}_{20} \mathrm{H}_{26} \mathrm{NO}$ : 296.2014, found: 296.2000 .

1-(4-Fluorophenyl)-6,6-dimethyl-2-phenyl-1,5,6,7-tetrahydro$4 \mathrm{H}$-indol-4-one (4i). ${ }^{1} \mathrm{H}$ NMR $\left(\mathrm{CDCl}_{3}, 400 \mathrm{MHz}\right) \delta: 1.10(\mathrm{~s}, 6 \mathrm{H})$, $2.42(\mathrm{~s}, 2 \mathrm{H}), 2.49$ (s, 2H), $6.77(\mathrm{~s}, 1 \mathrm{H}), 7.04-7.07$ (m, 2H), 7.09$7.12(\mathrm{~m}, 4 \mathrm{H}), 7.17-7.19(\mathrm{~m}, 3 \mathrm{H}) ;{ }^{13} \mathrm{C} \mathrm{NMR}\left(\mathrm{CDCl}_{3}, 100 \mathrm{MHz}\right) \delta$ : 28.6 (2C), 35.5, 37.0, 52.0, 105.6, $116.2 \& 116.4\left(\mathrm{~d},{ }^{2} J_{\mathrm{C}, \mathrm{F}}=23.0\right.$ $\mathrm{Hz}$ (2C), 119.9, 127.0 (2C), 128.2 (3C), $129.3 \& 129.4$ (d, ${ }^{3} J_{\mathrm{C}, \mathrm{F}}=$ $9.0 \mathrm{~Hz}$ ) (2C), 131.6, 133.6, 136.3, 144.6, $160.7 \& 163\left(\mathrm{~d},{ }^{1} J_{\mathrm{C}, \mathrm{F}}=\right.$ $247.0 \mathrm{~Hz}$ ), 193.9; HRMS (ESI) [M +1] calcd for $\mathrm{C}_{22} \mathrm{H}_{21} \mathrm{NOF}$ : 334.1607, found: 334.1600.

2-(4-Methoxyphenyl)-6,6-dimethyl-1-phenyl-1,5,6,7-tetrahydro-4H-indol-4-one (4j). Brown gum; ${ }^{1} \mathrm{H} \mathrm{NMR}\left(\mathrm{CDCl}_{3}, 400 \mathrm{MHz}\right)$ $\delta: 1.10(\mathrm{~s}, 6 \mathrm{H}), 2.42(\mathrm{~s}, 2 \mathrm{H}), 2.49(\mathrm{~s}, 2 \mathrm{H}), 3.69(\mathrm{~s}, 3 \mathrm{H}), 6.77(\mathrm{~s}, 1 \mathrm{H})$, 7.04-7.07 (m, 2H), 7.09-7.12 (m, 3H), 7.17-7.19 (m, 3H); ${ }^{13} \mathrm{C}$ $\mathrm{NMR}\left(\mathrm{CDCl}_{3}, 100 \mathrm{MHz}\right) \delta: 28.4,28.7,35.4,36.4,52.1,55.5,104.8$, 112.1, 119.6, 120.8, 126.4, 126.7, 127.7 (2C), 127.9 (2C), 129.6, 130.1, 132.2 , 136.7, 145.8, 155.1, 194.0; HRMS (ESI) $[\mathrm{M}+1]$ calcd for $\mathrm{C}_{23} \mathrm{H}_{24} \mathrm{NO}_{2}$ : 346.1807, found: 346.1812 .

4-(6,6-Dimethyl-4-oxo-1-phenyl-4,5,6,7-tetrahydro-1H-indol2-yl)benzonitrile (4k). ${ }^{1} \mathrm{H} \mathrm{NMR}\left(\mathrm{CDCl}_{3}, 400 \mathrm{MHz}\right) \delta: 1.10(\mathrm{~s}, 6 \mathrm{H})$, $2.439(\mathrm{~s}, 2 \mathrm{H}), 2.51(\mathrm{~s}, 2 \mathrm{H}), 6.91(\mathrm{~s}, 1 \mathrm{H}), 7.11-7.15(\mathrm{~m}, 4 \mathrm{H}), 7.42-$ $7.46(\mathrm{~m}, 5 \mathrm{H}) ;{ }^{13} \mathrm{C} \mathrm{NMR}\left(\mathrm{CDCl}_{3}, 100 \mathrm{MHz}\right) \delta: 28.5$ (2C), 35.5, 36.9, 51.9, 107.7, 118.6, 120.2, 127.5 (2C), 127.9 (2C), 128.8, 129.7 (2C), 131.9 (2C), 132.2, 134.1, 136.2, 137.1, 146.1, 194.0; HRMS (ESI) $[\mathrm{M}+1]$ calcd for $\mathrm{C}_{23} \mathrm{H}_{21} \mathrm{~N}_{2} \mathrm{O}: 341.1654$, found: 341.1644 .

4-(6,6-Dimethyl-4-oxo-1-(o-tolyl)-4,5,6,7-tetrahydro-1 $\mathrm{H}$-indol2-yl)benzonitrile (4l). ${ }^{1} \mathrm{H}$ NMR $\left(\mathrm{CDCl}_{3}, 400 \mathrm{MHz}\right) \delta: 1.07(\mathrm{~s}, 3 \mathrm{H})$, $1.11(\mathrm{~s}, 3 \mathrm{H}), 1.85(\mathrm{~s}, 3 \mathrm{H}), 2.16(\mathrm{~d}, J=16.8 \mathrm{~Hz}, 1 \mathrm{H}), 2.41-2.50(\mathrm{~m}$, $3 \mathrm{H}), 6.96(\mathrm{~s}, 1 \mathrm{H}), 7.13-7.16(\mathrm{~m}, 2 \mathrm{H}), 7.23(\mathrm{~d}, J=1.2 \mathrm{~Hz}, 1 \mathrm{H}), 7.28$ $(\mathrm{d}, J=0.8 \mathrm{~Hz}, 1 \mathrm{H}), 7.30-7.37(\mathrm{~m}, 1 \mathrm{H}), 7.39(\mathrm{~d}, J=1.6 \mathrm{~Hz}, 1 \mathrm{H})$, 7.40-7.43 (m, 2H); ${ }^{13} \mathrm{C} \mathrm{NMR}\left(\mathrm{CDCl}_{3}, 100 \mathrm{MHz}\right) \delta: 17.2,27.8,29.1$, 35.5 , 36.5, 52.05, 107.1, 110.0, 118.7, 120.1, 127.0 (2C), 127.3, 128.3, 129.7, 131.5, 132.1 (2C), 134.2, 134.2, 135.8, 136.4, 146.1, 193.7; HRMS (ESI) $[\mathrm{M}+1]$ calcd for $\mathrm{C}_{24} \mathrm{H}_{23} \mathrm{~N}_{2} \mathrm{O}: 355.1810$, found: 355.1805 .
4-(1-(2,3-Dimethylphenyl)-6,6-dimethyl-4-oxo-4,5,6,7-tetrahydro-1H-indol-2-yl)benzonitrile (4m). ${ }^{1} \mathrm{H} \mathrm{NMR}\left(\mathrm{CDCl}_{3}, 400 \mathrm{MHz}\right)$ $\delta: 1.36(\mathrm{~s}, 3 \mathrm{H}), 1.40(\mathrm{~s}, 3 \mathrm{H}), 2.02(\mathrm{~s}, 3 \mathrm{H}), 2.46(\mathrm{~d}, J=16.8 \mathrm{~Hz}, 1 \mathrm{H})$, 2.59 (s, 3H), 2.70-2.77 (m, 3H), $7.36(\mathrm{~s}, 1 \mathrm{H}), 7.38-7.44(\mathrm{~m}, 2 \mathrm{H})$, 7.50-7.52 (m, 1H), 7.54-7.55 (m, 1H), 7.57-7.59 (m, 1H) 7.69$7.72(\mathrm{~m}, 2 \mathrm{H}) ;{ }^{13} \mathrm{C} \mathrm{NMR}\left(\mathrm{CDCl}_{3}, 100 \mathrm{MHz}\right) \delta: 13.8,20.3,27.9,29.0$, 35.5 , 36.4, 52.0, 107.0, 109.9, 118.7, 120.0, 125.9, 126.5, 127.0 (2C), 131.0, 132.0 (2C), 134.3, 134.5, 136.3, 136.4, 139.1, 146.3, 193.8; HRMS (ESI) $[\mathrm{M}+1]$ calcd for $\mathrm{C}_{25} \mathrm{H}_{25} \mathrm{~N}_{2} \mathrm{O}: 369.1967$, found: 369.1951 .

2-(4-Chlorophenyl)-6,6-dimethyl-1-phenyl-1,5,6,7-tetrahydro$4 \boldsymbol{H}$-indol-4-one (4n). ${ }^{1} \mathrm{H} \mathrm{NMR}\left(\mathrm{CDCl}_{3}, 400 \mathrm{MHz}\right) \delta: 1.09(\mathrm{~s}, 6 \mathrm{H})$, $2.41(\mathrm{~s}, 2 \mathrm{H}), 2.50(\mathrm{~s}, 2 \mathrm{H}), 6.77(\mathrm{~s}, 1 \mathrm{H}), 6.96-6.98(\mathrm{~d}, J=8.4 \mathrm{~Hz}$, 2H), 7.11-7.14 (m, 4H), 7.41-7.42 (m, 3H); ${ }^{13} \mathrm{C} \mathrm{NMR}\left(\mathrm{CDCl}_{3}, 100\right.$ $\mathrm{MHz}) \delta: 28.6$ (2C), 35.5, 37.0, 52.0, 105.9, 120.2, 122.1, 127.1, 128.2 (2C), 128.3, 129.2 (2C), 131.5 (2C), 132.5 (2C), 136.2, 136.6, 144.4, 193.8; HRMS (ESI) $[\mathrm{M}+1]$ calcd for $\mathrm{C}_{22} \mathrm{H}_{21} \mathrm{NOCl}$ : 350.1312 , found: 350.1300 .

\section{Conclusion}

In conclusion, we presented a facile and effective protocol for the synthesis of 4-oxo-tetrahydroindole moieties using sulfamic acid. The entire reactions described in (Table 2) are very clean and provide high yield (88-98\%) under ball milling conditions. Moreover, a very short reaction time of $60 \mathrm{~min}$ was possible for the synthesis of 4-oxo-tetrahydroindoles derivatives (4a-n) compared to the very lengthy procedures reported for other methods. The relative results of current and earlier reported method for the synthesis presented in (Table 4) have demonstrated a significant development in terms of reaction yields, time and green protocol. Moreover, under ball milling conditions, solvent free, simple isolation and purification without column chromatography, mild sulfamic acid as recyclable promoter make the current synthetic approach environmentally benign and more attractive.

\section{Conflicts of interest}

There are no conflicts to declare.

\section{Acknowledgements}

The author T. L. Lambat would like to acknowledge the financial support through INSPIRE Fellowship [IF120418] research grant awarded from DST, New Delhi.

\section{Notes and references}

1 (a) H. K. Choi and W. S. Cho, Korean J. Chem. Eng., 2003, 20(4), 783-789; (b) T. L. Lambat, R. G. Chaudhary, A. Abdala, R. Mishra, S. Mahmood and S. Banerjee, RSC Adv., 2019, 9, 31683-31690; (c) H. Sharma, N. Singh and D. O. Jang, Green Chem., 2014, 16, 4922-4930; (d) B. C. Ranu and K. Chattopadhyay, in Eco-Friendly Synthesis of Fine Chemicals, ed, R. Ballini, Royal Society of Chemistry, Cambridge, UK, 2009, ch. 5; (e) A. Stolle, T. Szuppa, 
S. E. S. Leonhardt and B. Ondruschka, Chem. Soc. Rev., 2011, 40, 2317-2329; ( $f$ ) L. Rinaldi, K. Martina, F. Baricco, L. Rotolo and G. Cravotto, Molecules, 2015, 20(2), 2837-2849; $(g)$ T. H. El-Sayed, A. Aboelnaga, M. El-Atawy and M. Hagar, Molecules, 2018, 23(6), 1348; (h) K. Ardila-Fierro, A. Pich, M. Spehr, J. Hernández and C. Bolm, Beilstein J. Org. Chem., 2019, 15, 811-817; (i) A. Stolle, R. Schmidt and K. Jacob, Faraday Discuss., 2014, 170, 267-286; (j) M. Zille, A. Stolle, A. Wild and U. Schubert, RSC Adv., 2014, 4, 13126-13133; (k) R. A. Sheldon, Green Chem., 2005, 7, 267.

2 (a) J. Zhu and H. Bienayme, Multicomponent reactions, ed, Wiley-VCH, Weinheim, Germany, 2005; (b) T. Lambat, $J$. Chin. Adv. Mater. Soc., 2018, 6, 134-144; (c) C. F. Burmeister and A. Kwade, Chem. Soc. Rev., 2013, 42, 7660-7670; (d) T. Lambat, S. Deo, F. Inam, T. Deshmukh and A. Bhat, Karbala Int. J. Mod., 2016, 2, 63; (e) A. Saha, S. Payra and S. Banerjee, Green Chem., 2015, 17, 2859-2866; $(f)$ T. Lambat and S. Deo, J. Chin. Adv. Mater. Soc., 2016, 5(1), 20; $(g)$ T. Chatterjee, S. Bhadra and B. C. Ranu, Green Chem., 2011, 13, 1837-1842; (h) T. L. Lambat and S. S. Deo, J. Chin. Adv. Mater. Soc., 2017, 5(2), 65.

3 (a) M. R. Naimi-Jamal, J. Mokhtari, M. G. Dekamin and G. Kaupp, Eur. J. Org. Chem., 2009, 21, 3567-3572; (b) M. Ould M'hamed, Synth. Commun., 2015, 45, 2511-2528; (c) M. A. Ryashentseva, Chem. Heterocycl. Compd., 2006, 42, 1018; (d) G. Allan and M. Macielag, Expert Opin. Ther. Pat., 1999, 9, 7; (e) R. Rahmati, Arch. Iran. Med., 2012, 15(7), 433438; (f) M. Igarashi, Biosci., Biotechnol., Biochem., 2016, 81, 32-37.
4 (a) J. G. Hernández and E. Juaristi, Tetrahedron, 2011, 67, 6953-6959; (b) T. Chatterjee, D. Saha and B. C. Ranu, Tetrahedron Lett., 2012, 53, 4142-4144; (c) M. Nüchter, B. Ondruschka, W. Bonrath and A. Gum, Green Chem., 2004, 6, 128-141; (d) T. L. Lambat and S. S. Deo, Der Phar. Lett., 2014, 6(3), 218; (e) I. Lee, M. Kwon and C. Lee, Bull. Korean Chem. Soc., 2012, 33, 1; (f) C. Tanyeli, I. Akhmedov and E. Yazıcıoğlu, Tetrahedron Lett., 2004, 45, 9627-9629; $(g)$ N. Reddy, R. Mekala, S. Reddy, G. Siva and C. Bannoath, Synth. Commun., 2018, 48, 1649-1656.

5 (a) J. Clark, Acc. Chem. Res., 2002, 35, 791-797; (b) Z. Helwani, M. Othman, N. Aziz, J. Kim and W. Fernando, Appl. Catal., A, 2009, 363, 1-10; (c) T. Jin, G. Sun, Y. Li and T. Li, Green Chem., 2002, 4, 255-256; (d) J. Li, J. Han, J. Yang and T. Li, Ultrason. Sonochem., 2003, 10, 119-122; (e) N. Sato in Comprehensive Heterocyclic Chemistry II, ed. A. R.Katritzky, C. W. Rees and E. F. V. Scrivon, Elsevier Science Ltd, Oxford, 1996, vol. 6, pp. 233-278; (f) V. Mercalli, A. Massarotti, M. Varese, M. Giustiniano, F. Meneghetti, E. Novellino and G. Cesare Tron, J. Org. Chem., 2015, 80(19), 9652-9661; (g) T. L. Lambat, S. S. Deo and T. B. Deshmukh, J. Chem. Pharm. Res., 2014, 6(4), 888; (h) A. C. Boukis, B. Monney and M. A. R. Meier, Beilstein J. Org. Chem., 2017, 13, 54-62; (i) N. H. Jadhav, S. S. Sakate, N. K. Rasal, D. R. Shinde and R. A. Pawar, ACS Omega, 2019, 4, 8522-8527; (j) E. Martínez de Marigorta, J. M. de Los Santos, A. M. Ochoa de Retana, J. Vicario and F. Palacios, Beilstein J. Org. Chem., 2019, 15, 1065-1085; (k) J. Paul, M. Presset and E. Le Gall, Eur. J. Org. Chem., 2017, 17, 2386-2406. 